\title{
Food Security Status of Food Crop Farming Households in Crude Oil Producing Communities in Akwa Ibom State, Nigeria
}

\author{
Edet, Mfon Efiong ${ }^{1} \quad$ Arigor, Arigor John ${ }^{2} \quad$ Obuo, Peter Obuo ${ }^{1} \quad$ Ekong Juliana $^{1}$ \\ 1. Department of Agricultural Economics, University of Calabar, Calabar, Cross River State, Nigeria \\ 2. Department of agricultural Economics, Federal University of Technology, Owerri, Imo State, Nigeria
}

\begin{abstract}
The study analyzed the food security status of food crop farming households in selected crude oil producing communities in Akwa Ibom State, Nigeria. The specific objectives were to: describe the socio-economic characteristics of respondents; assess the food security status of farming households in the area; ascertain the determinants of food security status among farming households; analyse the effects of farming households' productivity on food security status of respondents; and make recommendations. Data collected from 270 food crop farming households were analyzed using the Logistic regression model,. The USDA approach was also employed to assess the food security status. From the findings, the study area was dominated by male $(55.6 \%)$, educated $(63.5 \%)$ and married (78.5\%) food crop farmers who were quite experience with average of 15 years of experience and mean household size of 9 persons. Majority $(62.2 \%)$ were full time farmers whose farms $(80.46 \%)$ were located within a distance of 1-5 kilometres. The assessment of the food security status of farming households revealed that majority $(85.9 \%)$ of the food crop farmers were food insecure while only $14.10 \%$ were food secure. A breakdown of the $85.9 \%$ shows that about $57 \%$ were food insecure without hunger, $21.9 \%$ were food insecure with moderate hunger while $7 \%$ were food insecure with severe hunger. The major determinants of aggregate food crop productivity were labour, farm size, expenditure on fertilizer, expenditure on planting materials, educational attainment and household size. Result of the productivity analysis shows that aggregate food crop productivity exerted significant positive influence on food security at the $1 \%$ level of significance. The study concluded that there is prospect for increase productivity among food crop farmers in the study area if productivity enhancing policies and startegies are adopted. The study recommends that there is need to educate food crop farmers, increase farm sizes and also reduce household sizes. Extension agents can be involved as well as awareness campaigns carried out to educate farmers on the need for family planning as well as on productivity enhancing strategies.
\end{abstract}

Keywords: Food Security, Food Crop, farming Households, Crude Oil

DOI: $10.7176 / \mathrm{JESD} / 12-12-06$

Publication date:June $30^{\text {th }} 2021$

\section{Introduction}

Nigeria is agrarian, and agriculture remains the hub of the economy, providing employment for over 90 percent of the rural dwellers, who constitute about 70 percent of the total population (LIMAN, 1979). Nigeria's strengths include abundant land, labor, and natural resources. Nigeria's strengths include abundant land, labor, and natural resources. This invariably leaves agriculture as a key sector capable of affecting majority of Nigerians in diverse ways. The persistence of hunger and poverty must therefore be to a large extent, the failure of the agricultural sector to fully impact positively on the people. The sector, in 2000, contributed 41.5 percent to the GDP, realized N16.3 billion from export of agricultural produce and produced 99.64 metric tonnes of different staples (CBN, 2000c and FOS, 1999). Relative to other African countries, Nigeria maintains a high rate of food production with a food output index of 157.4 based on 1989-91 (FAO, 2001). Despite these prospects, Nigeria's agricultural performance in recent times remains inadequate. Beside the inadequacy of the sector lies the foremost problem of low productivity which is a reflection of the fact that several strategies put in place by her Government have failed to turn around the fortune of the Agricultural sector.

According to Central Bank of Nigeria,CBN, (2011), in 1960, Nigeria had 60 percent of global palm oil, 2030 percent of global groundnut export and 15 percent of global cocoa export respectively, though these values later dropped by 5 percent in 2000. In the 1960 - 1969 period, the agricultural sector share of GDP averaged 56 percent but declined considerably to an average of 24 percent in the $1970-1979$ periods (FMARD, 2000), following the effect of the oil boom, leading to rising import bill and severe balance of payment problems. Its contribution to GDP in 2009 and 2010 were 40 and 42 percent respectively (National Bureau of Statistics, NBS and FMARD, 2011). However, total labour force engaged in agriculture declined from 71 percent in 1960 to about 55 percent in 1985 resulting in a considerable rise in unemployment. Furthermore its contribution to the export subsector also declined from 58.4 percent in the 1960-1970 to 5.2 percent in the 1971-1985 and declined further to 3 percent in the 1986-1995 (Adewusi, 2002). Consequently, Nigeria became a net importer of food and agricultural products with a total average import value of 630 million. These are clear indications that Nigeria's agriculture as a key component of the country has not maximized its potential due to low productivity and has implication for the attainment of food security. 
Several studies have attributed the abismal performance of the agricultural sector to the effect of the oil boom which had dominated Nigeria's economy from the mid-1970s (Olayide, 1980; Iwayemi, 1994 and Ijaija, 2000), providing over 90 percent of GDP (World Bank, 2009 and (International Monetary Fund, IMF, 2010), leading to neglect of the agricultural sector. However, in spite of the increasing rate of food insecurity and overdependence on oil by the economy since 1970, the country's rural economy still remain basically agricultural. Therefore, in reducing the rate of hunger and ensuring food sufficiency, the Nation requires a vibrant strategy that would focus on agricultural growth and employment creation in rural areas where majority of the poor reside.

In nigeria, Oil exploration is carried out in the Niger delta region of the country comprising of nine States namely; Akwa Ibom, Bayelsa, Cross River, Delta, Edo, Imo, Ondo Rivers and Abia States. Akwa Ibom State is a one of the world largest wetlands and the site of Nigeria's biodiversity; the area where the main oil reserves are found (Akpe, 2003). The discovery of oil in the State has necessitated the presence of several oil companies like Exxon Mobil, Universal Energy, Addax oil etc. whose activities have devastated the forest, wildlife, mangrove and fertile agricultural lands. In realization of the adverse effect of crude oil exploitation activities on agricultural productivity due to agitation by host communities and environmentalists, the oil companies embarked on several agricultural development activities within its area of operation. For instance, the Shell Petroleum Development Company and the Agip Oil Company have instituted several farming and fishery projects and have also embarked on series of agricultural project financing in the areas of poultry and livestock farming aimed at developing agriculture and enhancing income vis-a-vis reducing poverty in oil producing States.

The Federal Government on its part established the Oil Mineral Producing Areas Development Commission (OMPADEC) now Niger Delta Development Commission (NDDC) from Decree 23 of 1992 with agriculture and fishery as parts of its Directorates. The Commission has embarked on numerous agricultural development projects like the cassava

project at Okobo and the rice project in Ini Local Government Areas of the State, respectively (Niger Delta brief, 2007), though these projects are in extinction now. Several youths and women have also been trained on various agricultural skills in Songhai farm and numerous fishing equipment and gears distributed to fishermen.

Several studies have been carried out on the effect of oil exploitation activities on agricultural productivity in some Niger Delta generally, such as, Ukeagbu and Okeke (1987), Ezedike, (2000) and Olemeforo (2000); Ellis, (1994); Aigbokhan, (2003); Nnamdi, (1997); Igwe (1998). However, in Akwa Ibom State, studies by Ememugwem, (2005; 2009); Udofia, (2001); Inyang and Udo, (2005); had concentrated on the effect of oil exploitation on the environment.

There is seemingly no published work in the study area in terms of analyzing, food security status among the food crop farming households. It is against this background this study sought among other things to assess the food security status of food crop farming households in some selected crude oil producing communities in Akwa Ibom state.

In addressing this topic, some pertinent questions of interest as outline below will be askeded:

(i) What is the farming households' level of productivity in the study area?

(iii)What is the food security status of the food crop farming households?

(iv)What is the effect of farming households' productivity and other determinants on food security status of respondents?

The main objective of this study was to analyze the food security status of food crop farming households in selected crude oil producing communities of Akwa Ibom State Akwa Ibom State. However, the specific objectives were to:

(i) describe the socio-economic characteristics of respondents in the study area.

(ii) assess the food security status of farming house holds in the area.

(iii) ascertain the determinants of food security status of farming households in the area.

(iv) ascertain the effect of farming household productivity on food security status of respondents.

The study was guided by the following null hypotheses:

$\mathrm{H}_{\mathrm{O}}$ : Food crop farming households' productivity has no significant effect on food security status of households in the study area.

$\mathrm{H}_{\mathrm{O}}$ : Household food security is not significantly influenced by socioeconomic characteristics of farmers in the study area.

\section{Materials and Methods}

The study was carried out in crude oil producing communities of Akwa Ibom State. These communities are found in eight Local Government Areas of the State, namely, Eket, Esit Eket, Ibeno, Onna, Mbo, Eastern Obolo, Uruan, and Ikot Abasi. Akwa Ibom State is one of the South- South States in Nigeria and lies between latitudes $4^{0}, 321^{\text {' }}$ $\mathrm{N}$ and $5^{\circ}, 331^{\prime} \mathrm{N}$ and longitudes $7^{0} 251^{\prime}$ and $8^{0} 251^{\prime} \mathrm{E}$ of the Greenwich Meridian. The State is bordered on the East by Cross River State, on the West by Rivers State and Abia State and on the South by the Atlantic Ocean and the Southern-most tip of Cross River State. It covers an area of 7,081km $(2,734$ square metres with a population 
of over 2,359,736 people (NPC, 1991) and estimated population of 4,805,470 people (NPC, 2005). The State consists of thirty-one (31) Local Government Areas and is divided into six agricultural zones, namely:Abak agricultural zone (comprises Abak, Etim Ekpo, Ika, Ukanafun and Oruk Anam local government areas), Ikot Ekpene agricultural zone (comprises Ikot Ekpene, Essien Udim, Obot Akara, Ikono and Ini local government Areas), Etinan agricultural zone (comprises Etinan, Nsit Ibom, and Nsit Ubium local government areas) and Uyo agricultural zone (comprises Uyo, Ibiono Ibom, Uruan, Itu, Nsit Atai , Ibesikpo Asutan local Government Areas), Eket agricultural zone (consists of Eket, Esit Eket, Onna, Ibeno, Ikot Abasi Mlpat Enin and Eastern Obolo local Government Areas) and Oron agricultural zone that is made up of Oron, Urue-Offong/Oruko, Udung Uko, Okobo and Mbo local Government Areas, respectively.

The climate is typically tropical, hot and humid with two distinct identifiable seasons of rainy and wet seasons that last from mid-March to November and the dry season that occupies the rest of the year (FMARD, 2009). The major occupation of the people is farming and fishing. Major crops cultivated by indigenous farmers include crops like cassava, yam, cocoyam, maize, rice, plantain, banana, cowpea, melon, ginger, oil palm, coconut, and rubber. However, major livestock are poultry, pigs, goats, sheep, and cattle.

\section{Fig: 1. 0: Map of Akwa Ibom State showing crude oil producing Local Government Area}

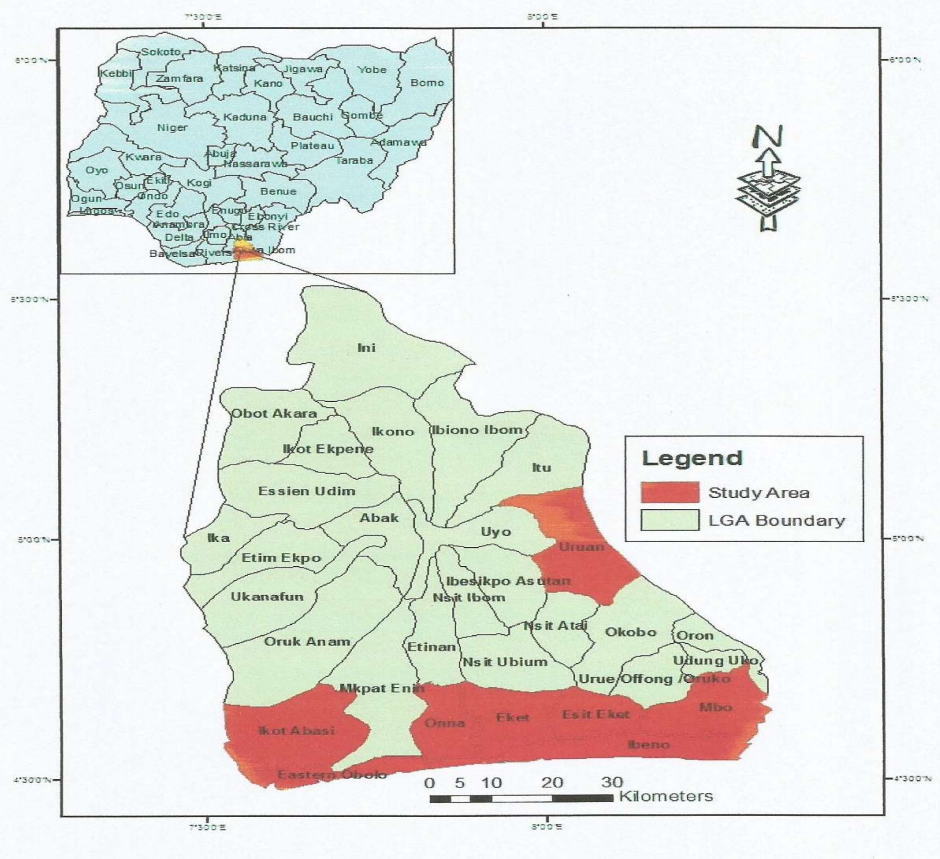

FIG.1: Map of Akwa Ibom State showing proposed LGAs

Fig:1 Map of Akwa Ibom State showing crude oil producing Local Government Areas

The population of this study comprises all registered farming households in the crude oil producing communities' of Akwa Ibom State. The total number of farming households in the study area was collected from the list of farming households that have registered with the Akwa Ibom State Ministry of Agriculture and Natural Resources.

\subsection{Sampling technique}

A multi-stage sampling technique was adopted in the study. Firstly, six (6) crude oil producing Local Government Areas (LGAs) were selected from existing eight (8) due to their levels of crude oil production. These are Eket, Esit Eket, Ibeno, Mbo, Ikot Abasi and Eastern Obolo respectively. Furthermore, three (3) communities were purposively selected from each of the selected local government areas, making a total of eighteen (18) communities. Again, seventeen (17) registered farming households were randomly selected from each of the communities making a total of three hundred and six (306) farming households. The essence of the uniform selection of respondents was to ensure unbiased and uniform comparison that would offer informed judgment based on findings. This was possible because the number of registered food crop farmers were many across the 
study area. However, only 270 questionnaires were retrieved and used for the study.

\subsection{Sources of data collection}

Data for the study were obtained from both primary and secondary sources. Primary data were collected using a set of structured questionnaire and administered with the help of trained field assistants. Secondary data were obtained from Niger Delta Development Commission (NDDC), Shell Petroleum Development Company (SPDC), Akwa Ibom State Agricultural Development Programme (AKADEP), Akwa Ibom State Ministry of Agriculture and Ministry of Environment as well as other Oil Companies and Oil related institutions within the State. However, the questionnaire was designed based on the study objectives and divided into two main sections. Section one clearly addressed questions based on the personal characteristics of the respondents, while section two addressed the research questions and objectives of the study.

\subsection{Data analysis}

Objective 1 was to describe the socio-economic characteristics of respondent in the area. Descriptive statistics (frequency distribution, mean percentages and standard deviations) were used.

Objective 11, which was to assess the food security status of the farming households in the area, was achieved using the United States Department of Agriculture (USDA) approach. In line with this approach, households were classified using a constructed food security scale that ranges from 0 to 10 . This scale indicates the extent of food security expressed by households in a single numerical value. The household scale is determined by their response to series of survey questions that were used to extract information from them. Accordingly, a household that has not experience any of the condition of food security indicated in the structured question was assigned 0 while those that has experience all of them were assigned 10, indicating that household with a higher scale value has responded affirmatively to more questions than those with fewer scale values.

The next step was to code the survey responses for food security scale. Here, household responses were categorized into "true", "most time true" and "not true". However, both "true" and "most time true" was taken as affirmative responses because both showed that the condition actually took place. Four categories that were defined in this purpose include the following: Food secure household; food insecure without hunger household; moderately food insecure households with hunger and severe food insecure household with hunger (Table 3.1).

Food secure households: These are households whose value ranges between 0 and 2.32 in the food security scale. They display either zero or minimal evidence of food insecurity.

Food insecure without hunger households: These are those whose value in the food security scale ranges from 2.33 to 4.56 .

Moderately food insecure household with hunger: These are households whose values range from 4.57 to 6.53 on the scale

Severely food insecure households with hunger: These are those households that experience severe and persistent hunger. Their values in the food security scale ranges from 6.54 to 10.0 .

Table 1: United States Department of Agriculture (USDA) Food Security Scale

$\begin{array}{cccc}\text { Food secure } & \begin{array}{c}\text { Food insecure } \\ \text { Without hunger }\end{array} & \begin{array}{l}\text { Food insecure with hunger } \\ \text { "moderate" }\end{array} & \begin{array}{c}\text { Food insecure with } \\ \text { hunger "severe" }\end{array}\end{array}$

Without hunger "moderate" hunger "severe"

Source: Adapted from United States Department of Agriculture (2000).

Objective II1, was to ascertain the determinants of food security status of farming households in the study area. This objective was achieved using the logistic regression approach. The implicit form of the model is given as:

$\mathrm{Z}_{\mathrm{i}}=\beta \mathrm{X}_{\mathrm{i}}+\mu$ .1

$Z_{i}=$ household food secure status (food secure household $=1$ while food insecure household $=0$ ).

$\mathrm{X}_{\mathrm{i}}=$ vector of explanatory variable

$\mu=$ error term

$\beta=$ vector of the parameter estimates

$\mathrm{X}_{\mathrm{s}}=$ explanatory variables and are defined as follows:

$\mathrm{X}_{1}=$ Educational status (number of years in school)

$\mathrm{X}_{2}=$ Farm size (hectares)

$\mathrm{X}_{3}=$ Marital status (Married $=1$ otherwise 0 )

$\mathrm{X}_{4}=$ income from farm $(\#)$

$\mathrm{X}_{5}=$ household size (number of persons)

$\mathrm{X}_{6}=$ age of farmers (years)

$\mathrm{X}_{7}=$ Sex of household head (male $=1$, otherwise $=0$ )

On a priori ground, $\beta_{1}, \beta_{2}, \beta_{3}$, and $\beta_{4}$ are expected to be positive; $\beta_{5}$ is expected to be negative while $\beta_{6}$ and $\beta_{7}$ are 
expected to be either negative or positive.

Objective 1V was to ascertain the effect of farming household productivity on food security status of respondents of crop farmers. This was achieved using the logistic regression model. The implicit form of the model is expressed thus:

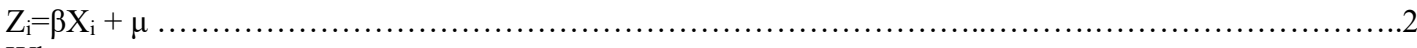

$\mathrm{Z}_{\mathrm{i}}=$ household food security status (food secure household $=1$, food insecure household

$\mathrm{X}_{\mathrm{i}}=$ vector of explanatory variables

$\mu=$ stochastic error term

$\beta=$ vector of the parameter estimates

$\mathrm{X}_{\mathrm{s}}=$ the explanatory variables defined as follows:

$\mathrm{X}_{1}=$ farm size (hectares)

$\mathrm{X}_{2}=$ labour (man days)

$\mathrm{X}_{3}=$ capital (number of equipment, naira equivalent).

$\mathrm{X}_{4}=$ Aggregate productivity of farming households

\subsection{Analytical technique}

Scientific data can be analyzed using variety of tools. The first set of common simple but important analytical tools used in analyzing data is the descriptive statistics. These include: frequency distribution, mean, simple percentages, standard deviation etc. Some data which require in-depth analysis also require the use of complex analytical tools for their analysis. The choice of each technique depends on the study objectives, data availability, time and budget (Mc Nally and Othman, 2002). For the purpose of this study, the following models were used in addition to the descriptive statistical tools:

\subsubsection{Multiple regression analysis}

This is an econometric tool used to estimate variables (Koutsoyannis, 1977). It is used to define how changes in a given variable (dependent variable) affect other variables (independent variables). The independent variables are used to induce change or explain the behaviour of dependent variable. The multiple regression models can be explained implicitly or explicitly. Mathematically, the implicit form is expressed as:

$\mathrm{Y}=\mathrm{f}\left(\mathrm{X}_{1}, \mathrm{X}_{2}--\mathrm{X}_{\mathrm{n}}\right)+\mu$

Where:

$\mathrm{Y}=$ dependent variable

$\mathrm{X}_{1}-\mathrm{X}_{\mathrm{n}}=$ independent variables

$f=$ functional relationship between $X_{\mathrm{s}}$ and $\mathrm{Y}$

$\mu=$ error term which accounts for the influence of various errors.

The explicit form can be expressed as:

$\mathrm{Y}=\mathrm{b}_{\mathrm{o}}+\mathrm{b}_{1} \mathrm{x}_{1}+\mathrm{b}_{2} \mathrm{x}_{2}+\ldots \mathrm{b}_{\mathrm{n}} \mathrm{x}_{\mathrm{n}}-\ldots+\mu$.

Where:

$\mathrm{Y}=$ dependent variable

$\mathrm{b}_{\mathrm{o}}=$ constant intercept

$b_{1}-b_{n}=$ parameters estimates (coefficients)

$\mu=$ error term

$\mathrm{x}_{1}-\mathrm{x}_{\mathrm{n}}=$ explanatory variables used for the estimation.

\subsubsection{Logistic regression model}

This model extends the technique of multiple regression analysis to research situation in which the outcome is categorical (e.g discontinuous) (Daryton, 1992). The model is best suited for describing and teaching hypothesis about relationships between a categorical outcome variable and one or more categorical or continuous predictor variable. Although it can accommodates categorical outcome that are all polychromous. This study focused on discontinuous outcome only i.e for secure household or not secure.

Theoretically, the hypothetical population proportion of cases for where $\mathrm{Y}=1$ is defined as $\Pi=\mathrm{n}(\mathrm{y}=1)$. Then, vertical proportion of cases for only $y=0$ is $1-\Pi=p(y=0)$. In the absence of other information, we need to estimate $\mathrm{p}$ by the sample population of cases for which $\mathrm{y}=1$. However, in the regression context, it is assumed that there is a set of predictor variables $\mathrm{x}_{1}-\mathrm{x}_{\mathrm{n}}$, these are related to $\mathrm{y}$ and hence provide additional information for predicting y. For theoretical mathematical reason, logistic regression analysis (LRA) is bound on a linear model for the natural logarithms of the odds in favour of $y=1$. According to Peny, Lee and Ingerssu, (2002), the simple logistic model has the form:

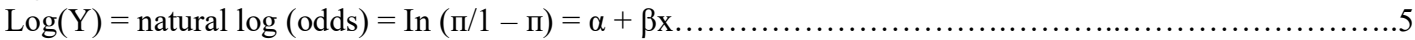

Taking the antilog of equation (3.8) on both sides, one derives an equation to predict the probability of the occurrence of the outcome of interest as follows: 
$\Pi=$ probability $(\mathrm{Y}=$ outcome of interest $/ \mathrm{x}=\mathrm{n}$, a specific value of $\mathrm{x}) \mathrm{e}+\beta \mathrm{x} / 1+\mathrm{e}^{\alpha}+$

Where $\Pi=$ the probability of the outcome of interest or event such as food secure household,

$\alpha=$ is the Y intercept,

$\beta=$ is the regression coefficient and

$\mathrm{e}=2.71828$ is the base of the system of natural logarithm,

$\mathrm{x}=$ can be categorical or continuous,

$\mathrm{Y}=$ is always categorical.

In line with equation (3.10), the relationship between the probability of $\mathrm{Y}$ and $\mathrm{X}$ is non-linear. As a result, the natural logarithm transformation of the odds in equation (3.10) is necessary to make the relationship between a categorical outcome variable and its predictor(s) linear.

Extending the logic of the simple logistic regression to multiple predictors $\mathrm{X}_{1} \ldots \ldots \ldots . . \mathrm{X}_{\mathrm{n}}$, one can construct a complex logistic regression for $\mathrm{Y}$ (household for food security status) as follows:

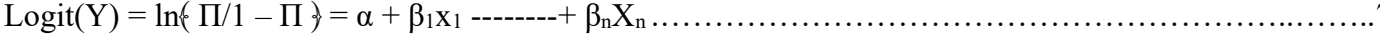

Therefore,

$\Pi=$ probability $\left(\mathrm{Y}=\right.$ outcome of interest $\left(\mathrm{X}_{1}=\mathrm{x}_{1}, \mathrm{X}_{\mathrm{n}}=\mathrm{x}_{\mathrm{n}}\right)$

$=\mathrm{e}^{\alpha+} \beta_{1} \mathrm{X}_{1-\cdots} \ldots+\beta_{\mathrm{n}} \mathrm{X}_{\mathrm{n}} / 1+\mathrm{e}^{\alpha}+\beta_{1} \mathrm{X}_{1}+\ldots+\beta_{\mathrm{n}} \mathrm{X}_{\mathrm{n}}$

Where:

$\Pi=$ is the probability of the event

$\alpha=$ is the $\mathrm{Y}$ intercept

$\beta_{\mathrm{s}}=$ are regression coefficient and

$\mathrm{X}_{\mathrm{s}}=$ are a set of predictors

$\alpha_{\mathrm{s}}$ and $\beta_{\mathrm{s}}$ are typically estimated by the maximum likelihood (ML) method which is preferred over the weighted last figure.

\subsection{Results and Discussion}

Most production, processing, marketing and consumption decisions of households are often times influenced by their socioeconomic characteristics. Among such characteristics considered in this study are: age, sex, marital status, farm distance, educational level, farming experience, household size, farm size, farming status, labour type utilization and cropping pattern.

\subsection{Socioeconomic Characteristics of Respondents}

The distribution of respondents with respect to their socio-economic characteristic is presented in Table 4.1. From the Table, about $55.6 \%$ of respondents were male, while $44.4 \%$ were female. This indicated that both male and female participated actively on food crop production in the study area and is capable of impacting positively on crop productivity in the area. Based on age, $73.7 \%$ of the respondents were in the age bracket of 41-60 years with an average age of 53 years. This shows that there was high proportion of middle aged and old farmers in the study area that participated in food crop production. Preponderance of old farmers can be attributed to rural urban drift of young people to the town in search of white collar jobs, leaving behind the aged adult members of the household to engage in farming. Most of respondents were married (78.5\%), 13.7\% widowed and 4.1\% single. The implication of the prevalence of married respondents is an indication that there is a tendency for large household size which by extension translates into available labour for farm work. It was also observed that majority of the respondents $(63.3 \%)$ were literate while about $36.7 \%$ never had any knowledge of formal education. The high educational attainment in the area would impact positively on food crop productivity. The distribution of respondents according to the distance of their farms to their houses in kilometers showed that most $(80.4 \%)$ of the respondents' farms were located between a distance of less than 1 to 5 kilometers while about $19.6 \%$ were located between 5 kilometers and above. This suggested that a greater proportion of the farm lands were family lands that were closer to residential houses. Hence, rampant incidence of theft of farm produce would be greatly reduced. Farmers in the area, were quite experience with average of 15 years' experience. A greater $(68.5 \%)$ proportion of respondents had more than 11 years of experience while $31.4 \%$ had between 1 - 10 years of experience. This later group of respondents was the more educated farmers who farmed on part-time basis and engages more on off-farm activities. Household size ranged from 1 to 20 persons with a mean of 9 persons per household. Result further revealed that majority of the respondents $(55.9 \%)$ had a household size of $6-10$ persons, followed by $25.6 \%$ that had a household size of 11-15 persons while about $2.9 \%$ had a household size of more than 15 persons. This is an indication that majority of farming respondents had a large family. As observed in the Table, most of the respondents (45.6\%) had less that 1 hectare, followed by $32.2 \%$ that planted between 1 and 2 hectares. About $20.4 \%$ planted more than $2-4$ hectares while only $1.8 \%$ planted more than 4 hectares respectively. The high proportion of respondents cultivating less than one hectare is an indication that farming was carried out on small scale basis. It was further revealed that majority (62.2\%) of respondents were full-time farmers, while $37.8 \%$ were 
part-time farmers that spent half of their time on the farm and made most of their income from non-farm activities. This indicated that most of the farmers interviewed had farming as their major occupation. Higher proportion of the respondents $(68.5 \%)$ utilized both family and hired labour in their farming operations while $20.7 \%$ and $11.11 \%$ made use of hired and family labour respectively. The low use of family labour despite the huge household sizes in the study area is an indication that majority of the available labour is not utilized in farm work. This might have been channeled into the off-farm subsector, probably because of the non-lucrative nature of farming in developing countries. The various cropping pattern adopted by farmers in the study area revealed that a greater $(78.9 \%)$ of respondents practiced mixed cropping, $15.6 \%$ sole cropping while 5.5\% combined mixed and sole cropping together. The high adoption of mixed cropping pattern may be an attempt to make maximum and efficient utilization of available farmlands.

TABLE 2: Socio-economic characteristics of respondents

\begin{tabular}{|c|c|c|}
\hline Variable & Frequency & Percentage \\
\hline \multicolumn{3}{|l|}{ Sex } \\
\hline Male & 150 & 55.6 \\
\hline Female & 120 & 44.4 \\
\hline Total & 270 & 100 \\
\hline \multicolumn{3}{|l|}{ Age } \\
\hline $20-30$ & 18 & 6.7 \\
\hline $31-40$ & 33 & 12.2 \\
\hline $41-50$ & 125 & 46.3 \\
\hline $51-60$ & 74 & 27.4 \\
\hline Above 60 & 20 & 7.4 \\
\hline Total & 270 & 100 \\
\hline Mean & 53 & \\
\hline \multicolumn{3}{|l|}{ Marital Status } \\
\hline Single & 11 & 4.1 \\
\hline Married & 212 & 78.5 \\
\hline Divorced & 10 & 3.7 \\
\hline Widowed & 37 & 13.7 \\
\hline Total & 270 & 100 \\
\hline \multicolumn{3}{|l|}{ Education } \\
\hline No Formal Education & 72 & 26.7 \\
\hline Primary & 60 & 22.2 \\
\hline Secondary & 99 & 36.7 \\
\hline Post secondary & 39 & 14.4 \\
\hline Total & 270 & 100 \\
\hline \multicolumn{3}{|l|}{ Farm distance } \\
\hline$<2$ & 129 & 47.8 \\
\hline$>2-5$ & 88 & 32.8 \\
\hline$>5-8$ & 40 & 14.8 \\
\hline$>8$ & 13 & 4.6 \\
\hline Total & 270 & 100 \\
\hline \multicolumn{3}{|l|}{ Farming experience } \\
\hline $1-5$ & 20 & 7.4 \\
\hline $6-10$ & 65 & 24.1 \\
\hline $11-15$ & 62 & 23.0 \\
\hline $16-20$ & 56 & 20.7 \\
\hline$>20$ & 67 & 24.8 \\
\hline Total & 270 & 100 \\
\hline Mean & 15 & \\
\hline \multicolumn{3}{|l|}{ Household size } \\
\hline $1-5$ & 42 & 15.6 \\
\hline $6-10$ & 151 & 55.9 \\
\hline $11-15$ & 69 & 25.6 \\
\hline$>15$ & 8 & 2.9 \\
\hline Total & 270 & 100 \\
\hline Mean & 9 & \\
\hline
\end{tabular}




\begin{tabular}{ccc}
\hline & & \\
\hline Variable & Frequency & Percentage \\
\hline Farm size & 123 & 45.6 \\
$<1$ & 87 & 32.2 \\
$1-2$ & 31 & 11.5 \\
$>2-3$ & 24 & 8.9 \\
$>3-4$ & 5 & 1.8 \\
More than 4 & $\mathbf{2 7 0}$ & $\mathbf{1 0 0}$ \\
Total & 102 & 37.8 \\
Farming status & 168 & 62.2 \\
Part time & $\mathbf{2 7 0}$ & $\mathbf{1 0 0}$ \\
Full time & & \\
Total & 30 & 11.11 \\
Labour type & 56 & 20.74 \\
Family & 184 & 68.15 \\
Hired & $\mathbf{2 7 0}$ & $\mathbf{1 0 0}$ \\
Family and hired & & \\
Total & 213 & 78.9 \\
Cropping pattern & 42 & 15.6 \\
Mixed cropping & 15 & 5.5 \\
Sole cropping & $\mathbf{2 7 0}$ & $\mathbf{1 0 0}$ \\
Mixed/ sole cropping & &
\end{tabular}

Source: Field survey, 2016

\subsection{Food security status of food crop farmers}

The analysis of the food security status of respondents was carried out using the USDA (2000) approach that was earlier discussed in chapter three. Result presented in Table 4.7 revealed that majority (85.9\%) of the food crop farmers were food insecure while only $14.10 \%$ were food secure. A breakdown of the $85.9 \%$ shows that about $57 \%$ were food insecure without hunger, $21.9 \%$ were food insecure with moderate hunger while $7 \%$ were food insecure with severe hunger. This finding agrees with Fakayode et al., (2009) who reported that about $12.2 \%$ of the country's household was food secured. It also conflicts with Ibok et al., (2014) who reported that only about $1.84 \%$ of urban food crop farmers in Cross River State were food secured.

TABLE 3: Food security status and daily food consumption of respondents

\begin{tabular}{lll}
\hline Variable & Frequency & Percentage \\
\hline Food Security Status & & \\
Food secure & 38 & 14.1 \\
Food insecure without hunger & 154 & 57.0 \\
Food insecure with moderate hunger & 59 & 21.9 \\
Food insecure with severe hunger & 19 & 7.0 \\
Total & $\mathbf{2 7 0}$ & $\mathbf{1 0 0}$ \\
\hline
\end{tabular}

Source: Field survey, 2016

\subsection{Determinants of Food Security status of respondents}

The result of the maximum likelihood estimate of the Logit model that was used to estimate the determinants of food security status among food crop farmers as presented in Table 4.8. From the result, with respect to predictive efficiency, the model predicted the food security status of food crop farming households with $98.74 \%$ accuracy. The estimated model yielded Pseudo $\mathrm{R}^{2}$ value of 0.2728 , implying that about $27.28 \%$ of the total variation in food security is explained by all the explanatory variables included in the model. The log- Likelihood ratio (LR) was 35.699 and significant at the 1 percent levels denoting the appropriateness of the estimated model. Empirical result revealed that the coefficient of education was positive and significant at $1 \%$ level of probability, implying that education increases the chances of food security. The coefficient of its marginal effect (0.0039) indicates that a unit increase in years of education would increase household food security by 0.391 percent. This is expected because it is an enlightenment tool that offers people opportunity to make social, economic, financial and other objective decisions. This finding corroborates those of Ibok et al. (2014), Asogwa and Umeh, (2012) and Babatunde et al., (2007). The slope coefficient of farm size was positive and significant at 10 percent, indicating that an increase in farm size would increase the chances of food security of farming households. The magnitude of the coefficient of its marginal effect $(0.0011)$ shows that a unit increase in farm size would increase the household chances of being food secure by 0.11391 percent. This is in line with a priori expectation and is expected 
because increase in farm size would imply increase in output and, hence, increase in food supply for farming households. This result supports Ibok et al., (2014), who reported a positive significant effect of farm size on food security in Cross River State. The variable household size carried the expected negative sign and was significant at $10 \%$ level of significance. This implies that an increase in household size would reduce household chances of being food secure. Judging from the coefficient of its marginal effect $(-0.0049)$, a unit increase in household size would reduce the probability of household food security by $0.4939 \%$; this is so because increase in household size would imply additional mouth to feed. This is capable of imposing unnecessary pressure on the household budget. This result compares favorably with Ibok et al., (2014), Amaza et al., (2009) and Olagungu et al., (2012).

TABLE 4: Logit result for determinants of food security

\begin{tabular}{|c|c|c|c|}
\hline Variable & Coefficient & $\mathbf{Z}$ & Marginal Effect \\
\hline Constant & -2.2375 & -0.96 & \\
\hline Education & 0.3139 & $4.01 * * *$ & 0.0039 \\
\hline Farm size & 0.0915 & $1.93 *$ & .0011 \\
\hline Marital status & 0.1036 & 0.12 & 0.0013 \\
\hline Farm income & $1.63 \mathrm{E}-06$ & 1.07 & $2.03 e-07$ \\
\hline Household size & -0.3969 & $-1.93 *$ & -0.0049 \\
\hline Age & -1.2180 & -0.89 & -0.0152 \\
\hline Sex & -0.5911 & -0.86 & -0.0072 \\
\hline Pseudo $\mathrm{R}^{2}=$ & 0.2728 & & \\
\hline Log- Likelihood $=$ & $-35.6999 * * *$ & & \\
\hline \multicolumn{4}{|c|}{ Percentage of correct prediction $=98.739$} \\
\hline Prob $>\mathrm{Chi}^{2}=$ & 0.0004 & & \\
\hline
\end{tabular}

Source: Field survey, 2016

3.4 Effect of productivity variables on food security

The result of the maximum likelihood estimates of the logit is shown in Table 4.9. A Pseudo $\mathrm{R}^{2}$ value of 0.1558 was obtained, implying that about $15.58 \%$ of the variation on food security status is explain by all the explanatory variables included in the model. The log- likelihood (LR) ratio value of -94.1213 was significant at the $1 \%$ level denoting the appropriateness of the estimated model. The result further revealed that the slope coefficient for farm size was positive and statistically significant at the $5 \%$ level meaning that it has a positive effect on food security. The marginal effect has a coefficient of 0.0060 denoting that, if the farm size is increase by 1 unit, the probability of household being food secure would increase by $6.02 \%$. This is an indication that the higher the farm size, the higher the household chances of being food secured. This result agreed with Ibok et al., (2014). More so, the coefficient for productivity which was the basis for this analysis was also positive and significant at the $1 \%$ level of significance indicating that food security increases with increasing productivity. The coefficient $(0.1432)$ of its marginal effect implies that a unit increase in the productivity of farming household would increase their food security status by $14.32 \%$. Similar finding was reported by Liverpool-Tasie et al., (2011) and Ibok et al., (2014).

TABLE 5: Logit result of the effect of productivity variables on food security

\begin{tabular}{llll}
\hline Variable & Coefficient & $\mathbf{Z}$ & Marginal effect \\
\hline Constant & -6.2385 & -5.45 & \\
Farm size & 0.5894 & $2.38^{* *}$ & 0.0600 \\
Labour & 0.0001 & 0.04 & $1.12 \mathrm{e}-06$ \\
Capital & $-4.02 \mathrm{e}-06$ & -0.75 & $-4.09 \mathrm{e}-06$ \\
Total productivity & 1.4069 & $4.88^{* * *}$ & 0.1433 \\
$\begin{array}{l}\text { Pseudo R }{ }^{2}=0.1558 \\
\text { Percentage of correct prediction }=0.1151\end{array}$ & \\
$\begin{array}{l}\text { LR chi }{ }^{2}=34.75 \\
\text { Prob }>\mathrm{Chi}^{2}=0.0000\end{array}$ & & \\
\hline
\end{tabular}

Source: Field survey, 2016

3.4.1 Strategies adopted by respondents against food insecurity

The coping strategies adopted by food crop farmers against food insecurity are presented in Table 4.10. These strategies ranged from allowing children to eat first to picking left-over food at social gathering. About 82.64\% allowed children to eat first, $74.9 \%$ bought food on credit, $57.69 \%$ eat once a day while $45.23 \%, 26.58 \%$ and $13.59 \%$ eat wild fruit, sold their assets and pick left over food at social functions respectively 
TABLE 6.0: Distribution of respondents based on strategies adopted against food insecurity

\begin{tabular}{lcccc}
\hline Coping strategy & Very often & Regularly & Occasionally & Never \\
\hline Eating of wild fruits & 5.1 & 1.8 & 38.87 & 54.23 \\
Buying food on credit & 3.1 & 1.8 & 7.1 & 25.10 \\
Eating once a day & 8.49 & 4.2 & 45 & 42.31 \\
Selling of assets & 1.4 & 9.96 & 15.22 & 73.42 \\
Allowing children to eat first & 6.55 & 1.48 & 74.61 & 17.36 \\
Picking of leftover food at & & & & \\
Social functions & 0.0 & 0.38 & 13.21 & 86.41 \\
\hline
\end{tabular}

Source: Field survey, 2016

\subsection{Conclusion}

The study has successfully analyzed the food security status among food crop farming households in eighteen crude oil producing communities in Akwa Ibom State, Nigeria. Result has shown that aggregate productivity of farming households was low but contributed significantly to food security status. This resulted in seviere food insecurity and rising poverty among food crop farmers in the study area. There was also low consumption of cereal and meat and fish in the study area reflecting the high deficiency in protein in the study area. The study made a case for the enhancement of food security and reduction of poverty through increase in productivity of food crops. The study concludes that there is prospect for increased productivity among food crop farmers in the study area if productivity enhancing policies and strategies are adopted. The sooner the better if the following policy recommendations are adhered to.

\subsection{Recommendations}

The following recommendations evolved from the findings:

Majority of the food crop farmers were food in-secured while the major determinants of food security were educational attainment, farm size and household size. Therefore, to enhance food security, there is need to educate food crop farmers, increase farm sizes and also reduce household sizes. Extension agents can be involved as well as awareness campaigns carried out to educate farmers on the need for family planning as well as on productivity enhancing strategies.

\section{REFERENCES}

Akintayo, O. I. (2011). Output differentials, total factor productivity and factor use intensity in rain-fed rice production systems in Ekiti and Niger States. Unpublished PhD seminar presentation, University of Ibadan, Nigeria.

Adejoh, S. D. (2009). Analysis of production efficiency and profitability of yam-based production systems in Iumu LGA of Kogi State. Unpublished M. Sc thesis, Ahmadu Bello University, Nigeria.

Adewuyi, S. A. (2006). Resource use productivity of rural farmers in Kwara State, Nigeria. International Journal of Agricultural Science, Environment and Technology, 1(1), 123-138.

Ajibolade, E. O. (2005). Effects of land acquisition for large scale farming on the productivity of small scale farming in Okitipupa LGA, Ondo State. M.Sc thesis, Federal University of Technology and Agriculture, Akure, Nigeria.

Ayantoye, K. (2009). Food insecurity status and transitions among rural households in South Western Nigeria. Unpublished $\mathrm{PhD}$ thesis, University of Ibadan, Nigeria.

Adebayo, C. O., Sanni, S. A., \& Baiyegunhi, I. J. (2012). Microcredit Scheme Impact and Food Security of Beneficiaries in Kaduna State: A Propensity Score Matching Approach. African Journal of Agricultural Research, 7(37), $5191-5197$.

Adewuyi, S. A. (2002). Resource Use Productivity in Food Crop Production in Kwara State, Nigeria (Unpublished Thesis, University of Ibadan), Department of Agricultural Economics.

African Development Bank (2006). Annual Statistical Report for the Nigeria's Economy, Abuja: AFDB Publication.

Agbonika, D. A., \& Aiyedun, E. A. (2009). Sustainable Food Security: The Nigerian Experience. Proceedings of the $26^{\text {th }}$ Annual Conference of Farm Management Association of Nigeria, $15-19^{\text {th }}$ October, 2012.

Aigbokhan, B. E. (2003). Challenges and other Options for Social Welfare Development in the Niger Delta. Paper prepared for the West African Institute for Financial and Economic Management, Lagos.

Akpe, S. (2003, May 14). Of NDDC, oil Companies and Abandoned Projects. The Punch, p.14.

Amaza, P., Abdoulaye, T., Kwaghe, P., \& Tegbaru, A. (2009). Changes in Household Food Security and Poverty in PROSAB area of Borno State, Nigeria. International Institute of Tropical Agriculture (IITA). Ibadan, Nigeria pp. $14-36$.

Amu, L. A. (1992). A Review of Nigeria’s Petroleum Industry, NNPC, Lagos. 
Central Bank of Nigeria (2000). Annual Report and Statement of Account, December, 2000.

Central Bank of Nigeria (2011). Interpreting Nigeria's Agricultural and Financial Value Chains: The Role of Nigerian Incentive Based Revenue Sharing for Agricultural Lending (NIRSAL), November 16, 2011.Civil and Environmental Research, 2(3)38.

Enemugwen, J. H. (2005). Petroleum Degradation of the Niger Delta Environment of Nigeria 1956 - 2004. Port Harcourt: MSS 2005, pp. $5-7$.

Enemugwen, J. H. (2009). Oil Pollution and Eastern Obolo Human Ecology 1957-2007. International Multidisciplinary Journal, 3(1), $136-151$.

Ezedike, C. E. (2000). Environmental Setting of Projects: In Agu, E. I. C. (ed). The Concept and Procedures of Environmental Impact Assessment, Owerri: Crystal Publishers.

Fakayode, S. B., Babatunde, R. O. \& Ajao, R. (2009). Productivity analysis of cassava-based production systems in the Guinea savannah: Case study of Kwara State, Nigeria. American-Eurasian Journal of Scientific Research, 3(1): $33-39$.

Fanegan, I. A. (2010). Effects of farm size on the productivity of cassava in Ife-South andAyedaade LGAs of Osun State, Nigeria. Unpublished B.Sc project, Obafemi Awolowo University, Ile-Ife, Nigeria.

Fasoranti, M. M. (2006). A stochastic frontier analysis of effectiveness of cassava-based cropping systems in Ondo State, Nigeria. Unpublished PhD thesis, Federal University of Technology and Agricultuure, Akure, Nigeria.

Food and Agriculture Organization (FAO) (1999) Rome Declaration on Food Security and World Food Summit. Plan of action November 13-17 Rome: FAO.

Food and Agriculture Organization (FAO) (2001). Production Year Book. Vol. 1.55

Food and Agriculture Organization (FAO) (2008). Urgent action needed to combat hunger as number of undernourished in the world increases. Retrieved December 15, 2005 from www.fao.org.

Fakayode, S. B., Rahji, M. A., Oni, O. A. \& Adeyemi, M. O. (2009). An Assessment of Food Security Status of Farm Households in Nigeria: A USDA Approach. The Social Sciences. 4(1), $24-29$.

Federal Ministry of Agriculture, Water Resources and Rural Development (2000). Agricultural Policy for Nigeria, Lagos. pp. $1-9$.

Federal Ministry of Agriculture, Water Resources and Rural Development (2011). Agricultural Transformation Agenda - FMARD, Abuja - pp. 7 - 17.

Food and Agricultural Organization (2010). The State of Nigeria Agriculture. African Reappraisal Review, pp. 17 -28 .

Ibok, O. W., Bassey, N. E., Attairet, E. A., \& Obot, O. J. (2014). Food security Determinants among Urban food crop farming households in Cross River State, Nigeria. Asian Journal of Agricultural Extension, Economics and Sociology, 3(1), 76-90.

Ibok,O. W, Idiong, I. C., Bassey, N. E., \& Udoh, E. S. (2014). Food Security and Productivity of Urban Food Crop Farming Household in Southern Nigeria. Agricultural Science, (293), 1 - 12.

Idrisa, Y. I, Gwary, M. M.,.\& Shehu, H. (2008). Analysis of Food Security Status among Farming Households in Jere Local Government Area of Borno State, Nigeria, Journal of Agriculture, Food, Environment and Extension, 7(3), 199-205.

Idumah, F. O. (2006). Productivity differentials among food cropp farmers in the Niger Delta. Unpubliished PhD thesis, University of Ibadan, Nigeria.

Igwe, N. (1998). The Effect of Crude Oil Exploration on Rural Agriculture. A Case Study of Ohaji/Egbema Local Government Areas of Imo State, (Unpublished MSc. thesis Imo State University), Department of Agricultural Economics and Extension, Owerri.

Ijaiya, G. T. (2000). Economic Growth in Nigeria: An Asymmetry of the Believed Growth Doctrine. In Usman, A. and Ijaiya, G. T. (Eds.). Selected Essays on the Contradictions of Economic Development Theories in Nigeria. Illorin: Haytec Publishing Company.

Inyang, L. D., \& Udo, J. (2005). Tropical Issue in Nigeria Oil and Gas Producing Industry. Unweld Communication Limited, Nigeria. pp. $56-77$.

Iwayemi, A. (1994). Perspective and Problems of Economic Development in Nigeria: 1960- 1990. Ibadan: Clear. Koutsoyannis, A. (1977). Theory of Econometrics. Macmillan Publishing Company.

Liman, A. (1979), "Overview of the Crops Sector" In the Crop Sub sector in the Fourth National Development Plan (1981 - 85). Proceedings of Workshop Organised by FDA, 29 - 30 Aug.

Mariya-Dixton, B., Akinyele, I. O., Oguntona, E. B., Nokoe, S., Sanusi, R. A., \& Harris, E. (2004). Nigeria Food Consumption and Nutrition Survey (2001 - 2003 summary). International Institute for Tropical Agriculture (IITA), 1 - 30 Ibadan.

McNally, R. and Othman, M. S. H.(2002). Environmental Economics: A Practical Guide, Malaysia WWF -UK.

Muhammed-Lawal, A., \& Atte, O. A. (2006). Analysis of agricultural production in Nigeria.African Journal of General Agriculture, 2(1): 1- 6.

Muhammed-Lawal, A., \& Omotesho, O. A. (2008). Cereals and Farming Households Food Security in Kwara 
State, Nigeria. Agricultural Journal, 3(3), 235-240.

National Bureau of Statistics and Federal Ministry of Agriculture and Rural Development (2012). Collaborative Survey on National Agriculture Sample Survey (NASS), Draft Report, Abuja.

National Bureau of Statistics (2010). Labour Force Survey 2009. NBS No.476, pp. 13. Available also at http:// www.Nigeria.State gov.ng. Last account $16^{\text {th }}$ April, 2014.

Niger Delta Development Commission (2007). Contribution of each State to Nigeria Economy. Annual Report 2006. Port Harcourt.

Nnamdi, K. U. (1997). The Petroleum Economics of Nigeria in Retrospect. Vol. 2. Aba, Nigeria. Onuoha Printing and Publishing Company Limited.

Ojo, S. O. (2005). Improving labour Productivity and technical efficiency in food crop production: A panacea for poverty reduction in Nigeria. Food, Agriculture and Environment 2(2):227-231.

Oladeebo, J. O.,(2006). Technical Efficiency and Rural poverty among farmers in Nigeria: A gender perspective. Global Journal of Science Frontier Research, Agriculture and Veterinary Sciences, 12(8), 1-8.

Olayide, S. O. (1980). A Quantitative Analysis of Food Requirements Supplies and Demand in Nigeria, Ibadan, Nigeria: Ibadan University Press.

Olemeforo, P. M. C. (2000). Possible Socio-economic aspect of the new found oil and it's Exploration in Imo State. Paper presented at the inauguration of the Institute of Environment Managers in Owerri.

Olujimi, J. A., Adewumi, E. A., \& Odunwole, S. (2011). Environmental Implications of Oil Exploration in the Coastal region of Ondo State. Journal of Geography and Regional Planning, 4(3), 110 - 121.

Omonona, B. T., \& Agoi, G. A. (2007). An analysis of food security situation among Nigerian Urban households: Evidence from Lagos State, Nigeria. Journal of Central European Agriculture, 8(3), 397-406.

Omotesho, O. A., Adewumi, M. O., Muhammed-Lawal, A. \& Ayinde, O. E. (2006). Determinants of food security among the rural farming households in Kwara State, Nigeria. African Journal of General Agriculture, 2(1), 7-15.

Oseni, S. O. (2001). Econometric analysis of productivity of tuber crops in Nigeria (1966 - 1998). Unpublished M.Sc thesis, University of Ibadan, Nigeria.

Peke, O. R. (2008). Economiic analysis of food crop farming under Ekiti State ADP. Unpublished M.Sc thesis, Federal University of Technology and Agriculture, Akure, Nigeria.

Staatz, J., Boughton, M., Duncan, H. \& Donovan, C. (2009). Food security in developing countries. In L. Phoenix and L. Walter (Eds), Critical food issues: Problems and state-of-the-art solutions worldwide. Westport, CT: Praeger Publishers

Sengooba, T. (1994). Root Crops for Food Security in Africa. In: Akorode, M. O. (eds.). Proceedings of the $5^{\text {th }}$ Triennial Symposium of International Society of Tropical Root, Kampala, Uganda, pp.23 - 25.

Sajini, F. I. (2013). Socio-Economic Problems of Oil in Nigeria's Niger Delta. Journal of Ecology 4(2):126 -136.

Udofia, U. (2001). Impact of Oil Pollution on Women, Children and Communities, pp 3 - 5.

Ukaegbu, O. D., \& Okeke, A. O. (1987). Planning of Associated Gas in Oil Industry- Implication on Growth, Productivity and Yield of Selected Farm Crops in Izombe, in NNPC: The Petroleum Industry and the Nigerian Econument, Lagos. pp. $302-331$.

Umoh, G. S. \& Yusuf, S. A. (2009). An empirical analysis of the poverty status nd productivity of rural farmers in Obubra, Cross River State, Nigeria. The Nigerian Journal of Economic and Social Studies, 41(2), 259-273.

United Nations Development Programme (1999). United Nations Development Programme Report 2001- 2007. UNDP Nigeria.

United Nations Environmental Programme (UNEP, 2011). Environmental Assessment of Ogoni Land. Available online at http://www.unep.org/nigeria.

Yusuf, S. A. (2008). Social capital and household welfare in Kwara State. Nigeria Journal of Human Ecology, 23(30): $219-229$.

World Bank (2006). World Development Report: Attacking Poverty. Washington DC: World Bank. 